\title{
An Assessment of the Use of Electronic Databases by Academic Staff, Bowen University, Nigeria
}

\author{
Adekunle P. Adesola, Bowen University, Nigeria \\ (iD) https://orcid.org/0000-0003-0062-6786 \\ Oladipupo Ibukun Ojemola, Bowen University, Nigeria
}

\begin{abstract}
The study assessed the use of electronic databases by the academic staff of Bowen University, Nigeria. Descriptive analysis including percentage and frequency count was used to analyze the data. From the total population of 500 academic staff, a sample of 75 was taken using the simple random sampling technique. Questionnaire was used as the instrument for data collection in this study. The questionnaire used was a closed ended or structured questionnaire divided into two sections. Section A captures the respondents' biodata while Section B contained the structured items to achieve the research objectives. Five research questions were developed and answered by the study. The results show that the majority of the academic staff were aware of available e-databases and use them to improve teaching delivery and research output. Challenges encountered include inadequate time and an overwhelming workload. The study concludes by recommending a drastic reduction in workload, increasing bandwidth, hotspots, and entrenching customer-friendly policies in the library.
\end{abstract}

\section{KEYWORDS}

Academic Staff, Bowen University, E-Resources, Electronic Databases, Information Resources, Nigeria

\section{BACKGROUND TO THE STUDY}

The proliferation of information communication and emerging technologies have altered radically the way we gather, process, store, disseminate, seek and use information. Similarly, the convergence of Information Communication Technologies (ICTs) and other emerging technologies have turned the world into a global village and technology driven knowledge economy. No institution or individual is isolated from this technology revolution.

Libraries, traditionally restricted to brick, mortar and physical collection of paper-based manuscripts of books, periodicals and other information products and services have metamorphosed into libraries without walls offering cutting edge technology enhanced information services to its technology savvy patrons irrespective of space or time. Collections hitherto held within the walls of the libraries with limited access are now digitized and held electronically online or on site offering patrons unhindered access from remote locations. Thus, library collections are no longer limited to those that are acquired directly by the libraries but include those that are accessed by subscription from information aggregators. 
One of these information resources acquired by subscription/open access by most academic libraries is known as the electronic database. An electronic database can be described as collection of similar or interrelated records held in computers or computer mediated technologies. It can be open access or accessed by subscription. Tella, Orim, Dauda, and Suleiman (2018) define an electronic database as computerized information records consisting of organized pieces of information placed in to records. Within an electronic database, computer program assists the user in selecting desired pieces of data. Electronic databases include products such as periodical indexes, abstracts, directories, encyclopedias, dictionaries and other reference works. Electronic databases provide search facility to users by subject, type and title or key word with the Boolean logic features.

Because of technological advancements, the use of electronic databases has continued to gain prominence in tertiary institutions worldwide and many academics are availing themselves of the opportunity to exploit these resources to access relevant, current and up-to-date information for diverse purposes. Although not without its attendant challenges, the advantages of using electronic databases by academics are numerous. Most academics especially in Nigeria are saddled with enormous responsibilities that may hinder them from visiting the library but can access the contents of electronic databases from their comfort zones anytime. Furthermore, electronic databases save time, provide current and up-to-date information, facilitate teaching and research and provide easy access and retrieval to documents of interest.

However, despite the inherent advantages of e-databases over the traditional paper based information products coupled with the enabling environment, regular and alternative sources of power, robust Internet connectivity, lecturers in Bowen University are not making optimal use of these databases as gleaned from usage statistics. Thus, this research aims to unravel the mystery behind this phenomenon.

\section{Statement of the Problem}

The importance of using electronic databases to prepare teaching materials and facilitate research, coupled with the numerous advantages inherent in using electronic database as gleaned from available literature, should serve as impetus to the use of available electronic databases by academics, but the use pattern observed from usage statistics among Bowen University academics ran contrary to this expectation.

Also, various publications report challenges to the access and use of electronic information resources to include slow internet connection, limited access to PCs, lack of skills in searching for electronic information resources, unstable power supply, limited range of titles of resources, inability to access electronic information resources subscribed to by the institution from remote locations and lack of awareness of the resources by most of the users (Ahmed, 2013).

However, in Bowen University, most of the identified constraints have been taken care of as management has invested heavily in subscribing to reputable and prime databases and put in place adequate internet, power and other infrastructures to ensure optimal use of these resources. Despite this heavy investment, usage statistics generated from these resources show an abysmal use compared to the volume of investment. This study therefore seeks to unveil the mystery behind the abysmal use of these resources in Bowen University.

\section{Objectives of the Study}

The main objective of the study is to examine the use of electronic resources among academic staff at Bowen University. The specific objectives of the study are to:

1. Determine academic staff purpose of using electronic databases and identify point of access

2. Determine the perceived impact of electronic resources on academic staff teaching and research and ascertain the satisfaction level of Bowen University academic staff with electronic databases.

3. Identify hindrances to use and offer appropriate recommendations. 


\section{Research Questions}

1. What is the level and channels of awareness of the electronic databases by academic staff?

2. What is the frequency of use of electronic databases by academic staff?

3. What is the level of satisfaction with the electronic databases?

4. What benefits do academic staff derive from using electronic databases?

5. What factors hinder the use of e-databases by academic staff in Bowen University?

\section{LITERATURE REVIEW}

\section{Awareness of Electronic Database}

Several studies available to the researchers show a high level of awareness of e-databases among surveyed respondents. A study conducted by Tajafari (2014) in selected Iranian libraries reported a significant level of e-databases availability, awareness, accessibility and utilization by the respondents. Also, in a study conducted in Ghana, findings by Kwadzo (2015) show that majority of the respondents became aware of available databases through their lecturers and gained access through the central library. Contrary to their claim however, few of the available databases were actually concentrated on, reporting high level of satisfaction. The study also reported improved academic performance as a result of using the databases. Also corroborating the direct relationship between electronic databases utilization and academic enhancement, Mohammed, Alhassan and Oyedum (2018) confirmed in their study that the more the respondents use available databases, the more they excel in their academics in selected tertiary institutions in Niger state.

In a related study at Beheshti University by Dehghani, Asnafiand Hajizeinolabedini (2018), it was revealed that available electronic databases were heavily utilized as a result of being aware of their existence. The respondents in the study also expressed satisfaction with the databases especially those respondents with requisite information literacy skills.

Similarly, Ekere and Omekwu (2016) reported an appreciable level of availability of and satisfaction with, online databases and portals at the MTN digital library at the University of Nigeria, Nsukka. This is further corroborated by Mohammed and Akor, (2017) revealing a high subscription and usage of online databases by sampled participants in selected Nigerian federal university libraries.

Results of Olajide and Adedokun, (2018) found that most of the surveyed respondents were aware and use the available e-databases while about 30 per cent from the sampled population were unaware of available e-databases at AfeBabalola University, Ado-Ekiti. Likewise, Akinola, et. al. (2018) found that majority of the participants were generally aware of electronic databases under consideration. However, most of them were unaware of the individual electronic databases that are made available by the library for postgraduate students' use at the University of Ibadan

However, Aina (2014) revealed insufficient awareness by respondents thus leading to equally negligible accessibility and underutilization of online databases at Babcock University Business School. This position is further reinforced by Dukper-Bawa, Bawa and Arthur. (2018). The result of the study conducted at Tamale Technical University, Ghana indicated that majority of the respondents $(61 \%)$ were unaware of the existence of these electronic databases while those who claimed awareness (31\%) rarely used the databases for academic purpose.

\section{Determinants and Frequency of the Use of Electronic Databases}

Studies have shown that the use of online databases is determined by competency in the multidimensional aspects of information literacy. Furthermore, findings reveal that plurality of literacies including tools, critical thinking, social-structural, networking, emerging technology and publishing literacy skills are all required to use online databases which is an integral part of an institution's 
electronic information resources. In other words, there exists a link between information literacy skills and the use of electronic information resources. (Odede \& Nsibirwa, 2018).

Also, there exists a relationship between personality traits and e-library use of individual users such as students and academics, which could have a significant effect on their use of e-databases. (Behrenbruch, Söllner, Leimeister and Schmidt 2013). Other determinants of e-databases use according to Behrenbruch, et. al. (2013) are user perceptions of system characteristics, computerrelated personality traits, and general personality traits.

Thus, in Abubakar and Adetimirin (2015), computer self-efficacy was discovered to have had a linear relationship with participants' use of electronic database signifying that the more of technology literacy respondents are given, the more they use online databases for their academic work.

Similarly, Adeleke and Emeahara (2016) discovered that the underutilization of full-text databases by the respondents at the University of Ibadan was closely related to lack of basic search skills, hence hindering the students from accessing the myriad of e-resources including online databases therefore establishing a significant relationship between information literacy skills and use of electronic information resources.

Likewise, Bashorun, Isah and Adisa (2011) reported an insignificant use of bibliographic databases by the respondents that would have any meaningful impact on respondents' learning and research process as stated in the mission statement of the University of Ilorin. Also, Akinola, et. al. (2018) established that the use of electronic databases by respondents in their study is low with greater percentage rarely using the resource. However, Mohammed and Akor (2017) reported that a high percentage of the respondents use electronic databases frequently

\section{Purposes of Using Electronic Databases}

Available literature shows myriad of purposes prompting the use of e-databases by users.

Several purposes were adduced from surveyed literature as necessitating the use of databases by users including academic staff. Some of these are provision of current information, supporting teaching and learning needs of faculty staff as well as students. In addition, electronic databases facilitate new research, mechanize conservation, preservation as well as adding value to the collection of parent organization. It also facilitates seamless access to online resources, enhance capabilities and manipulation of information, supports e-learning and online research, supplement traditional print resources, increases productivity, ensures better service to users as well as making collection available and accessible, round-the-clock irrespective of location (Ajayi, Shorunke \& Aboyade, 2014; Hirsh, 2014; Kesavan, 2009).

Furthermore, e-databases promote efficient delivery of information economically to all users, enhance collaborative research efforts, strengthen collaboration and communication between and among researchers and take a leading role in generation and dissemination of knowledge (Trivedi, 2010). Electronic databases also provide quick access to peer-reviewed, accurate and comprehensive information (Khan, Khan \& Bhatti, 2011; Sinha, Singha \& Sinha, 2011). For Mohammed and Akor (2017), databases engender knowledge update, increase research output and facilitate knowledge sharing. As a precursor of academic excellence, databases assist in preparation of courseware, curriculum and self-educational development, generation of up-to-date information thus contributing to academic excellence.

Prominent among the databases discovered to be preferred by academic staff from available literature are EbscoHost, JSTOR, Research4life group comprising AGORA, HINARI, OARE, ARDI as well as Science Direct, ProQuest, ERIC Online, Medline, Springer Link and Magiran (Ajayi, Shorunke \& Aboyade, 2014; Chigbu, Njoku \& Uzoagba, 2016; Iroaganachi \& Izuagbe, 2018; Isiakpona \& Ifijeh, 2012; Omotayo, 2010).

In addition, the literature is replete with challenges confronting users of e-databases in Nigerian libraries. Among the myriads of challenges confronting users in their quest to use available databases as gleaned from available literature are inadequate information literacy skills, poor internet connectivity, 
paucity of fund, lack of information retrieval skills, insufficient computer systems, epileptic power supply (Ajayi, Shorunke \& Aboyade, 2014; Akinola, et. al., 2018; Bakare, et. al., 2013; Damilola, 2013; Egberongbe, 2011; Iroaganachi \& Izuagbe, 2018; Tella, et. al., 2018). Other hindrances identified in the literature are dislike for screen and the associated health hazards (Isah, 2010), download delay, inadequate search skills, subscription cost, lack of downloadable full-text and inadequate user training (Akpohonor \& Akpojotor, 2016; Iroaganachi \& Izuagbe, 2018).

\section{METHODOLOGY}

The study adopted a survey design as it allows the researchers to draw on a large sample that is representative of the total population. Similarly, the survey design was considered appropriate in this study because it allows the use of various data collection techniques such as questionnaires, interviews and observations. The population of the study consisted of academic staff of Bowen University, Iwo, Osun State, Nigeria. The total number of academic staff at Bowen University, Nigeria stands at 500 as at 2017/2018 academic session, spreading across the existing faculties (Bowen University 2017/ 2018 Annual Report).

From the total population of 500 academic staff, a sample of 75 was taken using the simple random sampling technique which gives every respondent in the population equal opportunity of being selected. This justifies the sample used in this study which is 75. A questionnaire was used as instrument for data collection in this study. The questionnaire used was a closed ended or structured questionnaire divided into two sections. Section A captures the respondents' bio-data while section B contained the structured items to achieve the research objectives. The instrument was validated to ensure both the content and construct validity.

To achieve the validity of the questionnaire, the instrument was given to two statisticians, for scrutiny and expert judgment. This is with the view for checking its appropriateness before administration. To achieve the reliability of the instrument used for data collection in this study, a split-half reliability method was used. The instrument was administered to twenty (20) academic staff from within (2) faculties in the university. Responses collected were subjected to Cronbach alpha. The overall reliability of the questionnaire returned $\mathrm{r}=0.51$.

The researchers personally administered the questionnaire to the respondents in their respective offices at the main campus of the University. Out of 75 copies of the questionnaire administered, 57 were returned completely filled representing $78 \%$ return rate. These were used for data analysis of the study.

Descriptive statistics including frequencies count and percentages were used in analyzing the collected data. Descriptive statistics including percentage and frequency count with a simple inferential statistics (ANOVA) were performed. This was because the two methods of data analysis are relevant to analyze the type of data collected. The results are presented as follows.

\section{Demographic Data}

There are a total of 59 respondents to our questionnaire, 64\% (38) are Males and 29\% (17) are females; $12(20 \%)$ are singles and $44(75 \%)$ are married. The distribution of the age of the respondents are 21 - 30 years, $10(17 \%) ; 31-40$ years, $22(37 \%) ; 41-50$ years, $17(29 \%) ; 51-60$ years, $6(10 \%)$ and those above 60 years, $3(5 \%)$. This shows that majority of the respondents are within the age groups of $31-40$ years and $41-50$ years old.

In terms of academic qualification, $3(5 \%)$ are B.Sc./B.A. degree holders, 33 (56\%) are M.Sc./M.A. and 21 (36\%) are Ph.D. degree holders respectively as shown in Fig. 1. This indicates that there were more male academic staff members and that a large proportion of respondents are married, likewise. Also, the respondents comprised of Master degrees holders, closely followed by Ph.D. degree holders. 
Table 1. Demographic Information of respondents

\begin{tabular}{|l|l|l|}
\hline \multicolumn{1}{|c|}{ Demographics } & Frequency & \% Frequency \\
\hline Gender & & \\
\hline Male & 38 & $64 \%$ \\
Female & 17 & $29 \%$ \\
Total & 55 & $93 \%$ \\
\hline Marital Status & & \\
\hline Single & 12 & $20 \%$ \\
Married & 44 & $75 \%$ \\
Total & 57 & $95 \%$ \\
\hline Age & & \\
\hline $21-30$ years & 10 & $17 \%$ \\
$31-40$ years & 22 & $37 \%$ \\
$41-50$ years & 17 & $29 \%$ \\
$51-60$ years & 6 & $10 \%$ \\
60 years and above & 3 & $5 \%$ \\
Total & 58 & $98 \%$ \\
\hline Academic Qualification & & \\
\hline BSc./B.A. & 3 & $5 \%$ \\
M.Sc./M.A. & 33 & $56 \%$ \\
Ph.D. & 21 & $36 \%$ \\
Total & 57 & $97 \%$ \\
\hline
\end{tabular}

Distribution of the rank of respondents are as follows: Teaching Assistant, 3 (5\%); Assistant Lecturer, 17 (29\%); Lecturer 2, 5 (9\%); Lecturer 1, 12 (20.3\%); Senior Lecturer, 5 (9\%) and Reader $3(5 \%)$. From this, it is observed that Assistant Lecturers and Lecturer 1 are in the majority.

Distribution by faculty shows respondents from faculty of Social and Management Sciences to be 32 (54\%), faculty of Science 13 (22\%), faculty of Agriculture 4 (7\%), faculty of Humanities 3 (5\%), faculty of Health Sciences 4 (7\%) and faculty of Education $3(5 \%)$ as shown in Fig. 2. This shows that majority of the respondents were from the faculties of Social and Management Sciences and Science.

\section{Level and Channels of Awareness of the Electronic Databases by Academic Staff}

$86 \%$ of the respondents claimed to be aware of e-database in Bowen University while $12 \%$ were not aware. (Table 2). A cross-tabulation of their awareness and the level of awareness revealed that $41 \%$ of those who claimed to be aware were highly aware, $57 \%$ claimed they were averagely aware, and $2 \%$ claimed to be scarcely aware. (Table 4 ).

The major channels of awareness by respondents are through the librarians (44\%) and announcements (27\%) (Table 3).

\section{Purpose of Using Electronic Databases by Academic Staff}

As shown in Table 5, 28\% of the respondents claimed that their use of electronic databases is to improve research output, 20\%; improved research output and teaching delivery, 15\%; improved teaching delivery while $25 \%$ of the participants did not indicate any response.

\section{The Frequency of Use of Electronic Databases by Academic Staff}

In their response to frequency of use of available electronic databases, $39 \%$ of the respondents indicated they use the electronic databases occasionally while $7 \%$ use it frequently and $19 \%$ rarely make use of the electronic resources as shown in Table 6. 


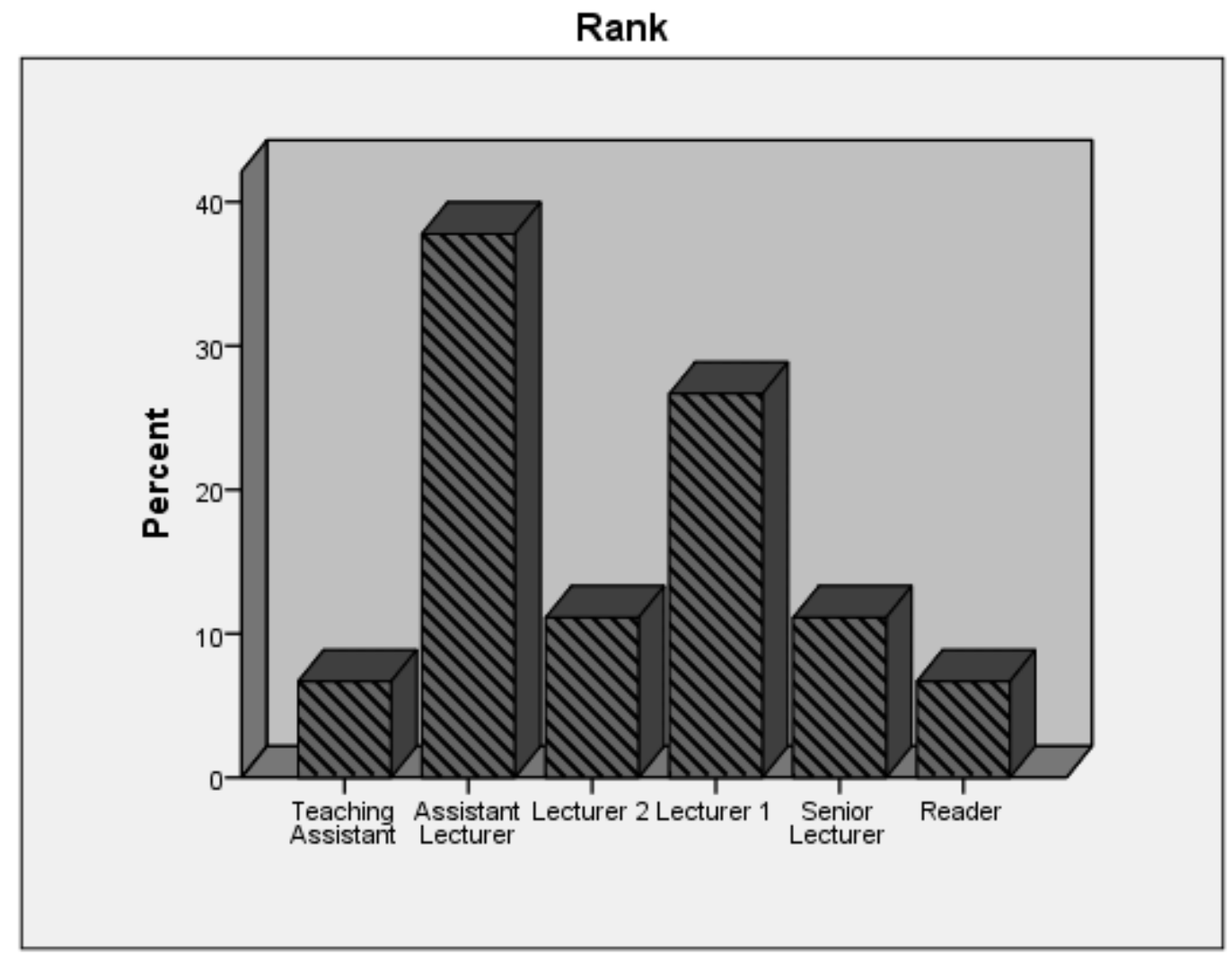

\section{Level of Satisfaction With the Use of Electronic Databases}

To determine the level of satisfaction of academic staff with the use of electronic databases, respondents were asked to state their level of satisfaction, Table 7 shows that $10 \%$ of the respondents were highly satisfied, $37 \%$ satisfied while $14 \%$ were never satisfied with the use of the electronic resources.

\section{Benefits Derived From Using Electronic Databases}

Table 8 shows responses to benefits derive from using electronic databases to include improved research (28\%), improved teaching delivery (15\%).

\section{Factors Hindering Academic Staff From Using Available Electronic Databases}

Participants responded that the challenges inhibiting them from making maximum use of the electronic databases as shown in Table 9 were the unfriendly interface and unfriendly library policies which characterise (2\%), workload (6\%), time constraints and availability of better alternatives (10\%) and poor internet access $(13 \%)$.

Is there a Significant Relationship Between the Length of Time the Respondents Have Been a Staff in Bowen University and their Usage of the E-resources?

$\mathbf{H}_{\mathbf{0}}$ : There is no significant relationship between the length of time the respondents have been a staff in Bowen University and their usage of the e-databases. 


\section{Faculty}

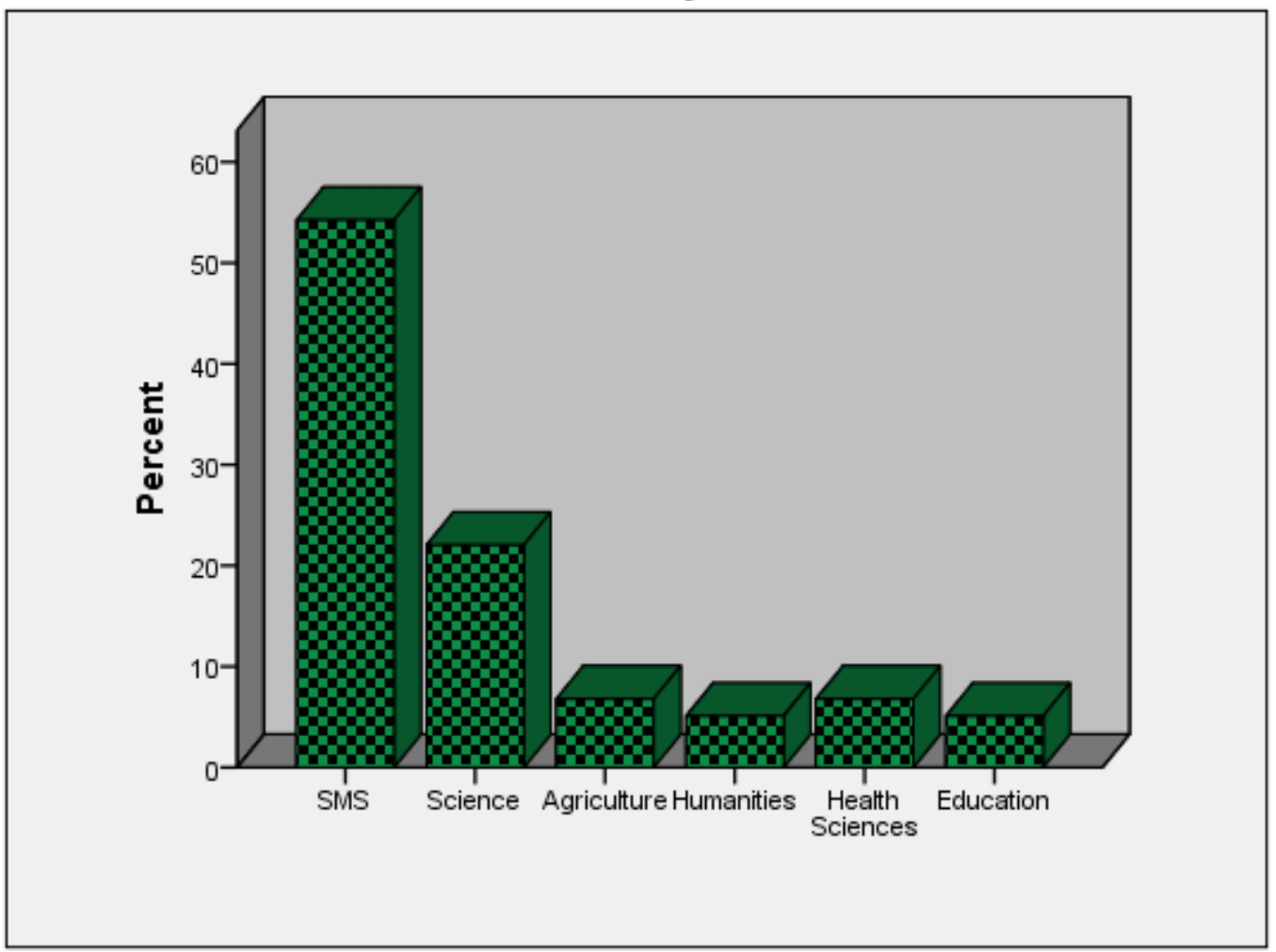

Table 2. Awareness of databases

\begin{tabular}{|l|l|l|}
\hline \multicolumn{1}{|c|}{ Are you aware of e-database available in the library? } & \multicolumn{1}{c|}{ Frequency } & \multicolumn{1}{c|}{ \% Frequency } \\
\hline Yes & 51 & $86 \%$ \\
No & 7 & $12 \%$ \\
No response & 1 & $2 \%$ \\
Total & 59 & $100 \%$ \\
\hline
\end{tabular}

Table 3. Channels of awareness

\begin{tabular}{|l|l|l|}
\hline \multicolumn{1}{|c|}{ Channel of awareness } & \multicolumn{1}{c|}{ Frequency } & \multicolumn{1}{c|}{ \% Frequency } \\
\hline Announcement & 16 & $27 \%$ \\
Through Librarians & 23 & $44 \%$ \\
Current awareness service & 3 & $5 \%$ \\
Memo & 2 & $3 \%$ \\
Chance discovery & 3 & $5 \%$ \\
Personal findings & 3 & $5 \%$ \\
No response & 6 & $10 \%$ \\
\hline Total & 59 & $100 \%$ \\
\hline
\end{tabular}


Table 4. Levels of awareness

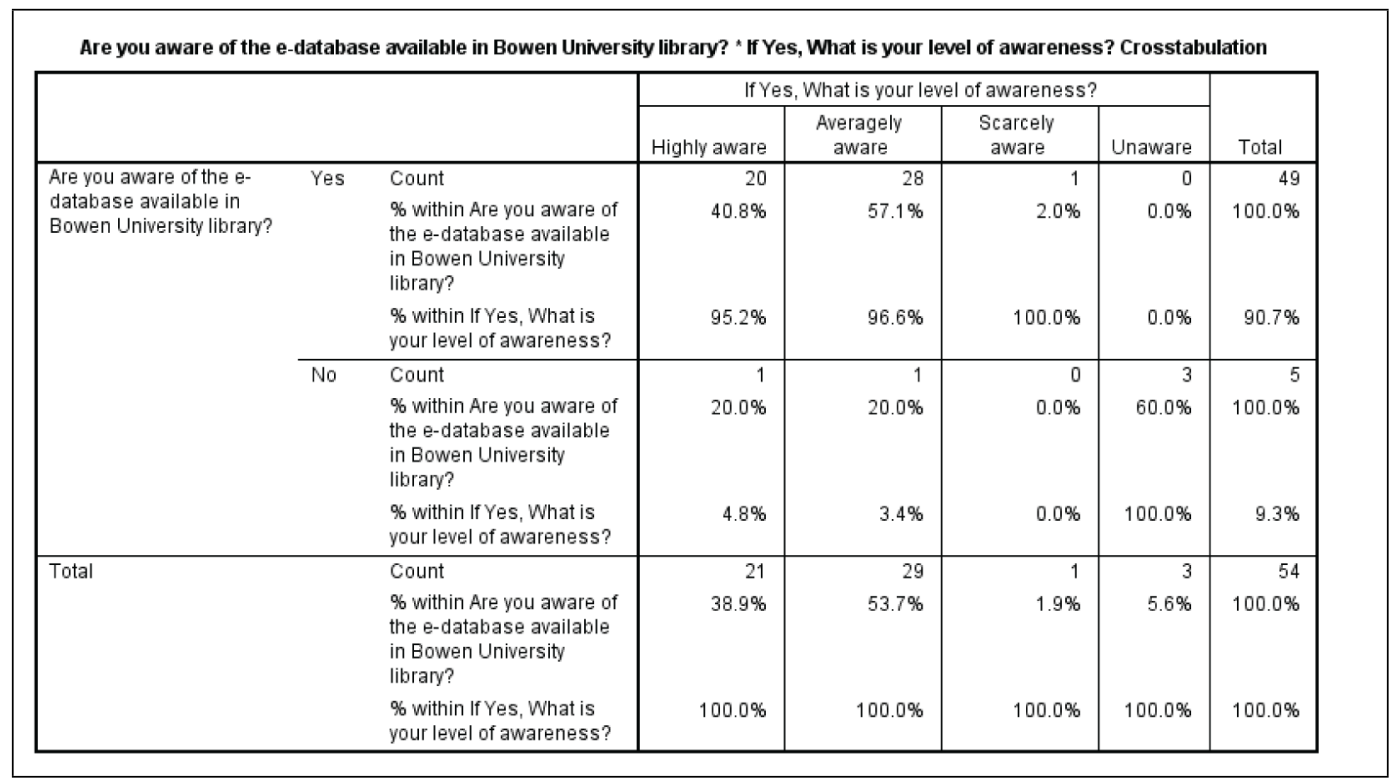

Table 5. Purpose of using electronic databases

\begin{tabular}{|l|l|l|}
\hline \multicolumn{1}{|c|}{ Purpose of using e-databases } & Frequency & \multicolumn{1}{c|}{ \% Frequency } \\
\hline Improved research output & 17 & $28 \%$ \\
Improved teaching delivery & 9 & $15 \%$ \\
Improved visibility & 3 & $5 \%$ \\
Increased collaborations & 3 & $5 \%$ \\
Improved research output and teaching delivery & 12 & $20 \%$ \\
No response & 15 & $25 \%$ \\
Total & 59 & $100 \%$ \\
\hline
\end{tabular}

Table 6. How often do you use the electronic databases

\begin{tabular}{|l|l|l|}
\hline \multicolumn{1}{|c|}{ Variables } & \multicolumn{1}{c|}{ Frequency } & \% Frequency \\
\hline Frequently & 4 & $7 \%$ \\
Occasionally & 23 & $39 \%$ \\
Rarely & 11 & $19 \%$ \\
Never & 6 & $10 \%$ \\
No response & 15 & $25 \%$ \\
Total & 59 & $100 \%$ \\
\hline
\end{tabular}


Table 7. Level of satisfaction with the use of electronic database

\begin{tabular}{|l|l|l|}
\hline \multicolumn{1}{|c|}{ Variables } & \multicolumn{1}{c|}{ Frequency } & \multicolumn{1}{c|}{ \% Frequency } \\
\hline Highly satisfied & 6 & $10 \%$ \\
Satisfied & 22 & $37 \%$ \\
Never satisfied & 8 & $14 \%$ \\
Undecided & 12 & $20 \%$ \\
No response & 11 & $18 \%$ \\
Total & 59 & $100 \%$ \\
\hline
\end{tabular}

Table 8. What benefits do you derive from using e-databases

\begin{tabular}{|l|l|l|}
\hline \multicolumn{1}{|c|}{ Variables } & \multicolumn{1}{|c|}{ Frequency } & \multicolumn{1}{c|}{ \% Frequency } \\
\hline Improved research output & 17 & $28 \%$ \\
Improved teaching delivery & 9 & $15 \%$ \\
Improved visibility & 3 & $5 \%$ \\
Increased collaborations & 3 & $5 \%$ \\
Improved research output and & 12 & $20 \%$ \\
teaching delivery & 15 & $25 \%$ \\
No response & 59 & $100 \%$ \\
Total & & \\
\hline
\end{tabular}

$\mathbf{H}_{1}$ : There is a significant relationship between the length of time the respondents have been a staff in Bowen University and their usage of the e-databases.

A chi-square test of independence was performed to test if there is a significant relationship between the length of time the respondents have been a staff in Bowen University and their usage of the e-resources. The chi-square value obtained is 5.216 with degrees of freedom 3 and 'p-value' 0.157 . Since the $p$-value is greater than the alpha level of 0.05 , the researchers fail to reject the null hypothesis and conclude that there is no statistically significant relationship between the length of time the respondents have been a staff in Bowen University and their usage of the e-databases.

\section{DISCUSSION}

While responding to level and channels of awareness, $86 \%$ of the respondents were aware of the availability of e-databases with $41 \%$ of being highly aware mostly through librarians (44\%) and announcements (27\%). In their response to the purpose of using electronic databases, $28 \%$ of the

Table 9. Challenges encountered

\begin{tabular}{|l|l|l|}
\hline \multicolumn{1}{|c|}{ Variables } & \multicolumn{1}{c|}{ Frequency } & \multicolumn{1}{c|}{ \% Frequency } \\
\hline Time & 6 & $10 \%$ \\
Workload & 4 & $6 \%$ \\
Poor internet access & 8 & $13 \%$ \\
Unfriendly library policies & 1 & $2 \%$ \\
I have better alternatives & 6 & $10 \%$ \\
Unfriendly interface & 1 & $2 \%$ \\
No response & 33 & $44 \%$ \\
Total & 59 & $100 \%$ \\
\hline
\end{tabular}




\section{Chi-Square Tests}

\begin{tabular}{|l|r|r|r|}
\hline & Value & df & $\begin{array}{c}\text { Asymp. Sig. } \\
\text { (2-sided) }\end{array}$ \\
\hline Pearson Chi-Square & $5.216^{\text {a }}$ & 3 & .157 \\
Likelihood Ratio & 6.613 & 3 & .085 \\
Linear-by-Linear & 1.937 & 1 & .164 \\
Association & & & \\
N of Valid Cases & 56 & & \\
\hline
\end{tabular}

respondents use electronic databases to improve research output, improve research output and teaching delivery (20\%) while $15 \%$ claimed improved teaching delivery is the reason they use e-databases.

Respondents were asked to indicate the frequency of use of electronic databases with $39 \%$ of the respondents indicating use the electronic databases occasionally, $7 \%$ frequently, and $19 \%$ rarely using electronic databases. On level of satisfaction, $10 \%$ were highly satisfied, $37 \%$ were satisfied while $14 \%$ were never satisfied with the use of the electronic resources. In their response to benefits, $28 \%$ returned improved research while $15 \%$ reported improved teaching delivery as the benefits they derived from using e-databases.

Asked to highlight challenges militating against use of available resources, $2 \%$ of respondents returned unfriendly interface and unfriendly library policies, $6 \%$ claimed workload was the challenge, $10 \%$ of the respondents claimed time constraints and availability of better alternatives discourage them from using available e-databases while $13 \%$ stated that poor internet access was their challenge.

\section{Implication to Research and Practice}

The study could improve best practices among librarians who are responsible for managing the electronic resources by exposing the challenges encountered in access and usage of these resources in addition to providing suggestions on how to improve access to and usage of electronic journals. The study will also contribute to the existing literature on the importance of accessing and using electronic journals that are subscribed to by various institutions particularly in a developing country context. As stated earlier, the implication of the study to research and practice lies in its revelation that availability of e-databases does not automatically translate to utilization. Other factors such as ease of access, time and enabling environment play significant role in determining level of use of these resources by academic staff.

\section{CONCLUSION AND RECOMMENDATIONS}

As stated inter alia, this study was propelled by the desire to unearth reason(s) for the abysmal use of available electronic databases in Bowen University despite the availability of steady internet network, power and other infrastructures. Results of the study have shown that availability does not necessarily translate to utilization. There could be other extraneous factors militating against use. Based on the findings of this study, the following recommendations are made:

- Internet bandwidth should be increased to facilitate unhindered access to the resources from all locations. 
- Access from remote locations should be well streamlined with proper authentication provided to authorized users.

- More internet hotspots should be created on campus to facilitate unhindered access.

- Periodic personalized and group trainings should be organized for staff to encourage use of these resources.

- Academic workload should be drastically reduced to create enough time for the academic staff to enhance access and usage of these resources.

- Similarly, the details of all databases subscribed to by the university should be made available to all the academic staff for easy access.

- E-libraries and computer laboratories should be provided at the departmental level to facilitate use.

- Since the library as a service unit is customer centered, customer friendly policies should be put in place to encourage and sustain patronage.

- Management should continue to subscribe to relevant discipline based and multidisciplinary databases to encourage use.

\section{Future Research}

This study has assessed the use of electronic databases by academic staff at Bowen University by identifying level and means of awareness, purpose, level of satisfaction and hindrances to use. Future research could focus on establishing user preference for either print or electronic resources so as invest more on the preferred choice rather that wasting scarce resources. Another area that could be investigated is determining users' awareness and use of next generation catalogs to retrieve information items from the library as this might greatly enhance use of available resources. Further research to determine the relevance and usefulness of specific databases to academic programs can also be carried out. 


\section{REFERENCES}

Abubakar, D., \& Adetimirin, A. (2015). Influence of computer literacy on postgraduates' use of e-resources in Nigerian university libraries. Library Philosophy and Practice (ejournal). Paper 1182. https://digitalcommons. unl.edu/libphilprac/1182

Adeleke, D. S., \& Emeahara, E. N. (2016). Relationship between information literacy and use of electronic information resources by postgraduate students of the University of Ibadan. Library Philosophy and Practice (e-journal). https://digitalcommons.unl.edu/libphilprac/1182

Adeniran, P. (2013). Usage of electronic resources by undergraduates at the Redeemer's University, Nigeria. International Journal of Library and Information Science, 5(10). http://www.academicjournals.org/IJLIS

Adesoye, A. E., \& Amusa, O. I. (2013). Use of electronic resources in health sciences institutions in Ogun State, Nigeria. PNLA Quarterly, 77(3), 28-41.

Ahmed, S. M. Z. (2013a). A survey of students' use of and satisfaction with university subscribed online resources in two specialized universities in a developing country. Library Hi Tech News, 30(3), 6-8. doi:10.1108/ LHTN-02-2013-0010

Aina, R. F. (2014). Awareness, accessibility and use of electronic databases among academic staff of Babcock University. Business School. Kuwait Chapter of Arabian Journal of Business and Management Review, 3(6).

Ajayi, S. A., Shorunke, O. A., \& Aboyade, M. A. (2014). The influence of electronic resources use on students' reading culture in Nigerian universities: A case study of Adeleke University, Ede, Osun State. Library Philosophy and Practice (e-journal). Paper 1182. https://digitalcommons.unl.edu/libphilprac/1182

Akinola, A. O., Shorunke, O. A., Ajayii, S. A., Odefadehan, O. O., \& Ibikunle, F. L. (2018). Awareness and use of electronic databases by postgraduates in the University of Ibadan. Library Philosophy and Practice (e-journal). 2065. https://digitalcommons.unl.edu/libphilprac/2065

Akpoghome, U. T., \& Idiegbeyan, O. J. (2010). The role of digital library in law research. International Journal of Library and Information Science, 2(6), 108-113.

Akporhonor, B. A., \& Akpojotor, L. O. (2016) Challenges confronting postgraduate library and information science student in the use of electronic resources in Southern Nigeria. Library Philosophy and Practice (e-journal). Paper 1319. https://digitalcommons.unl.edu/libphilprac/1319

Bakare, O. D., Owolabi, O. A., Banigboye, O. B., \& Bankole, O. M. (2013). Factors affecting library use by academic staff and students of Federal University of Agriculture. PNLA Quarterly.

Bashorun, M., Isaa, A. O., \& Adisa, M. Y. (2011). User perception of electronic resources in the University of Ilorin, Nigeria. Journal of emerging Trends in Computing and Information Sciences, 2(11). Retrieved from http://csjournal.org/journalofcomputing/archive10/27011/Vol.2.pdf

Behrenbruch, K., Söllner, M., Leimeister, J. M., \& Schmidt, L. (2013). Understanding Diversity-The Impact of Personality on Technology Acceptance Model. https://www.irit.fr/recherches/ICS/events/conferences/ interact2013/papers/810307.pdf

Chigbu, E. D., Njoku, E. O., \& Uzoagba, N. (2016). Management and usage of open access scholarly online resources in university libraries in Nigeria: Librarians' viewpoints. The Electronic Library, 34(6), 974-984. doi:10.1108/EL-08-2015-0140

Damilola, O. A. (2013). Use of electronic resources by Distance Students in Nigeria: The case of the National Open University, Lagos and Ibadan study Centers. Library Philosophy and Practice (e-journal). Retrieved from https://digitalcommons.unl.edu/libphilprac

Dehghani, N., Asnafi, A. R., \& Hajizeinolabedini, M. (2018), A survey on using online database byfaculty members and graduate students at Shahid Beheshti University. Library Philosophy and Practice (e-journal). 1980. https://digitalcommons.unl.edu/libphilprac/1980

Dukper-Bawa, K., Bawa, S., \& Arthur, B. (2018). Awareness and utilization of electronic library resources by students of Tamale Technical University, Ghana. Library Philosophy and Practice (e-journal). 2078. https:// digitalcommons.unl.edu/libphilprac/2078 
Egberongbe, H. S. (2011). The use and impact of electronic resources at the University of Lagos. Library Philosophy and Practice (e journal). Retrieved from http://digitalcommons.unl.edu/cgi/viewcontent.cgi?articl $\mathrm{e}=1490 \&$ context $=$ libphilprac

Ekere, J. N., \& Omekwu, C. O. (2016) Users' perception of the facilities, resources and services of the MTN digital library at the university of Nigeria, Nsukka. Library Philosophy and Practice (e-journal). Retrieved from https://digitalcommons.unl.edu/libphilprac

Hamzat, S. A., \& Mabawonku, I. (2018). Influence of performance expectancy and facilitating conditions on use of digital library by engineering lecturers in universities in South-West, Nigeria. Library Philosophy and Practice (e-journal). Retrieved from http://digitalcommons.unl.edu/libphilprac

Hirsh, K. (2014). Using university-supported digital library collections in the K-12 classroom. Durham, NC: North Carolina Central University Technology institute for Educators.

Iroaganachi, M. A., \& Izuagbe, R. (2018). Access to online databases: Predicate for faculty research output. Library Philosophy and Practice (e-journal). 2133. https://digitalcommons.unl.edu/libphilprac/2133

Isiakpona \& Ifijeh, G. (2012). Availability of electronic resources for service provision in university libraries in Ogun state Nigeria. Samaru Journal of Information Studies, 12(1\&2).

Kesavan, V. R. (2009). Digital library services: A practical approach for collection development, organization and management. Journal of Library. Information \& Tongxin Jishu, 1(1), 1-20.

Kwadzo, G. (2015). Awareness and usage of electronic databases by Geography and Resource Development Information Studies graduate students in the University of Ghana. Library Philosophy and Practice (e-journal). 1210. https://digitalcommons.unl.edu/libphilprac/1210

Mathew, S., \& Sornam, S. A. (2007). Use of e-resources among postgraduate students of Kerala Agricultural University. Kelpro Bulletin, 1(2), 13-24.

Melo, L. B., \& Pires, C. P. (2011). Measuring the economic value of the electronic scientific information services in Portuguese academic libraries. Journal of Librarianship and Information Science, 43(3), 146-156. doi:10.1177/0961000611411708

Mohammed, A. B., Alhassan, J. A., \& Oyedum, G. U. (2018). Impact of quality information resources on students' academic performance in tertiary institutions in Niger state, Nigeria. Library Philosophy and Practice (e-journal). 1978. https://digitalcommons.unl.edu/libphilprac/1978

Mohammed, S. A., \& Akor, P. U. (2017). Availability and utilization of electronic information databases for research by agricultural scientists in federal university libraries in North Central Nigeria. Library Philosophy and Practice, 381. https://digitalcommons.unl.edu/libphilprac/381

Odede, I., \& Nsibirwa, Z. (2018). Information literacy skills in using electronic information resources. Library Philosophy and Practice (e-journal). Retrieved from https://digitalcommons.unl.edu/libphilprac

Olajide, O. O., \& Adedokun, F. O. (2018). Awareness and use of electronic information resources by the faculty members of Afe Babalola University, Ado Ekiti (ABUAD): A survey. Library Philosophy and Practice (e-journal). https://digitalcommons.unl.edu/libphilprac

Omotayo, B. O. (2011). Access, use, and attitudes of academics toward electronic journals: A case study of Obafemi Awolowo University, Ile-Ife. Library Philosophy and Practice. Retrieved from http://unllib.unl.edu/ LPP/2010

Pandurangaswamy \& Kishore, K. (2013). Use of e-resources by postgraduate students of the institute for financial management and research (IFMR), Chennai, India. E-Library Science Research Journal, 1(12).

Sinha, M. K., Singha, G., \& Sinha, B. (2011). Usage of electronic resources available under UGC-INFONET digital library consortium by Assan University library users. In International CALIBER. Goa University, Goa. Retrieved on 18th June 2011, from http://www.shodhganga.inflibnet.ac.in/dxml/bitstream/handle/1944/164/50.pdf

Tajafari, M. (2014). Accessibility and use of electronic journals at Iranian university libraries. Library Philosophy and Practice (e-journal). https://digitalcommons.unl.edu/libphilprac/1135 
Tella, A., Orim, F., Dauda, M. I., \& Suleiman, A. M. (2018). The use of electronic resources by academic staff at the University of Ilorin, Nigeria. Education and Information Technologies, 23(1). Advance online publication. doi:10.1007/s10639-017-9577-2

Trivedi, M. (2010). Digital Libraries: Functionality, Usability, and Accessibility. Library Philosophy and Practice, 381. https://digitalcommons.unl.edu/libphilprac/381

Adekunle Adesola, a Certified Librarian of Nigeria (CLN), currently heads the Periodical Section of the library and had at various times headed the Cataloguing and Classification as well as Information Access Management sections of Bowen University Library, Iwo, Osun State, Nigeria. He holds a Bachelor of Science degree B. Sc. (Hons) Political Science and Master of Library and Information Studies (M.L.S.) both from the University of Ibadan. He has attended a lot of trainings, conferences and workshops on Social Media and Web 2.0 applications for information gathering, processing and dissemination, Open Source Management Software for institutional repository, etc. In addition to his highly demanding professional and administrative duties, Adekunle teaches information literacy as an academic librarian in Bowen University. A savant of information science and au fait with ICTs and library software, Adekunle has published sizable number of articles in reputable and peer-reviewed international journals. His research interests include social media applications, library software, assistive and interactive technologies, current and emerging ICTs, digital and information literacy.

Oladipupo Ibukun Ojemola is a researcher with background in Statistics from the undergraduate till the postgraduate studies. A lecturer in the department of Mathematics and Statistics, Bowen University, Iwo. 